Article

\title{
Do Women Affect the Final Decision on the Housing Market? A Case Study
}

\author{
Sabina Źróbek ${ }^{1, *(1)}$, Elżbieta Zysk ${ }^{1}$, Mirosław Bełej ${ }^{1}\left[\right.$ and Natalija Lepkova ${ }^{2}$ (I) \\ 1 Department of Spatial Analysis and Real Estate, University of Warmia and Mazury in Olsztyn, \\ Prawocheńskiego 15, 10-720 Olsztyn, Poland; elzbieta.zysk@uwm.edu.pl (E.Z.); \\ miroslaw.belej@uwm.edu.pl (M.B.) \\ 2 Department of Construction, Management and Real Estate Faculty of Civil Engineering, \\ Vilnius Gediminas Technical University Vilnius, 10221 Vilnius, Lithuania; natalija.lepkova@vgtu.lt \\ * Correspondence: zrobek@uwm.edu.pl
}

Received: 18 April 2020; Accepted: 4 June 2020; Published: 6 June 2020

\begin{abstract}
This article presents the results of research on the effect of the customer's gender on the tenure choice (ownership or tenancy) on the housing market. In the study, an attempt has been made to investigate whether there is a significant role of women in making decisions in this market. The survey was conducted among residents of two cities-Olsztyn (Poland) and Vilnius (Lithuania). The obtained answers were subjected to a multi-dimensional categorical and quantitative analysis. The results showed, among others, that women generally have greater decision-making autonomy in residential issues than men, with Lithuanian women doing this much more often than Polish women. However, it should be noted that the dominant decision-making model in the housing market is the model of joint decisions taken by men and women. The results of the conducted analysis broaden the existing knowledge of the functioning of the housing market and may support the implementation of the pro-social and pro-sustainable spatial development policy of the given territorial unit. The results may also contribute to more sustainable development of enterprises in the housing construction sector. This is an important issue in a climate of intense competition between "providers" of flats and the gradual introduction of the idea of competition between them and the social environment.
\end{abstract}

Keywords: customer gender; women; tenure choice; sustainable housing; housing market

\section{Introduction}

Sustainable housing is one of the areas of the economy that has a significant effect on the level of satisfying social needs, dynamics of economic processes and effectiveness of developmental activities. Improved housing increases the quality of life and contributes to the achievement of several sustainable development goals (SDGs), including those addressing health (SDG 3) and sustainable cities (SDG 11) [1]. The quality of housing has major implications for people's health. Housing in cities is of particular concern, with the world's urban population predicted to double by 2050 and, along with it, the demand for housing. A key pathway for providing healthy housing conditions and improving health is sustainable housing [2].

The interconnections between housing development and the economy indicate that the former plays a significant role in elevating the level of social, economic and spatial cohesion of a country [3,4]. Housing is a special type of commodity [5], because it is a spatially immobile, highly durable, highly expensive, multi-dimensionally heterogeneous and physically modifiable commodity. These characteristics shape attitudes and behaviors toward housing and, in turn, influence neighborhood characteristics, mortgage markets, national housing policies and urban growth and decline. A housing property constitutes the most expensive of all goods purchased throughout people's lives, and many citizens cannot afford their 
own place to live within their lifetime. The living conditions of citizens influence professional activity, qualifications and the spatial mobility of employees. Among numerous economic and sociological theories, there is unanimity concerning the extraordinary significance of the housing market in the life of an individual, society and state [6].

To ensure proper residing conditions is every person's aspiration, and this decision is among the most important ones to be made. This is because a flat or a single-family home satisfy several basic human needs, i.e., a sense of security, a sense of belonging to a place, location in the social hierarchy and diversification of investment capital. According to Renigier-Biłozor et al. [7] the need for housing takes one of the main places in the hierarchy of the importance of needs. With reference to Markov's well-known hierarchy of needs, a house or a flat not only provides the basis for the physiological necessity of shelter for all society [8] but is also a fundamental need to strive to find one's own place on earth [9], a sense of belonging [10] and a factor in the health of societies [11], and is considered as well as a main human right [12]. It is an integral and indispensable element of meeting needs virtually in every sphere of human life: in the sphere of security needs (for stability), social needs (home, meeting place), needs for recognition and respect (prestige, highlighting social position) and the need for self-realization (proof of independence). Thus, the need for a location and appropriate living conditions is most important to all people and remains relevant throughout their lives [2]. A significant proportion of households are able to satisfy their housing needs (flats or single-family houses) through ownership or tenancy [13]. The motives for buying an apartment can be varied. On the one hand, they may result from social needs (especially family needs); on the other hand, they may result from economic needs (deriving income from renting).

Research on the housing market is being conducted in Poland and Lithuania, but the authors usually analyze the preferences of young people, i.e., mainly students [14,15]. This is facilitated by the relative ease of obtaining survey data. However, there is little comprehensive research on the issue of making tenure decisions-to buy or to rent. According to Dziworska [16], this is undoubtedly a complex problem to which there is no unequivocal answer and, as scientists and practitioners, we are obliged to search for rational system solutions, as well as to improve the premises of decisions in the scope of choosing the housing tenure of satisfying their needs. However, the results of the study on the role of women in the housing market in the countries studied are not known to the authors of this article.

This situation encouraged the authors of this article to undertake more detailed research on this issue. For the purposes of the study, the following hypothesis was formulated: women have a significant role in decision-making in the housing market in Poland and Lithuania. In the paper, two legal rights for the flats are considered-ownership and tenancy—and when the term "housing market" is used, it means the market of flats (also called premises or dwellings). In Poland, the term "housing" means a premises for a permanent residence of persons-built or remodeled for residential purposes and structurally separated by fixed walls within a building, into which separate access leads from a staircase, passage, common hall or directly from a street, a courtyard or a garden, comprising one or several rooms and auxiliary spaces [17]. According to Statistics Lithuania [18], a dwelling (housing) is defined as a one-dwelling house, a part thereof, flat or other living quarters meant for a person or family to live in. The study was followed by a survey of Polish (Olsztyn) and Lithuanian (Vilnius) housing market customer attitudes. These two Baltic countries were selected because of some important common historical facts (Poland and Lithuania formed one common state and both were under the communist regime as separate countries), although there are differences in economic, political and cultural determinants typical of a particular country reflected in the behavior of customers of different genders in the housing market. The research involved respondents from Olsztyn (percentage of women 58.4) and Vilnius (percentage of women 61.9). The paper is structured as follows. After a short introduction to the research (Section 1), a theoretical basis of the conducted research is given in Section 2 together with an overview of historical and mindset-based determinants, demographic factors and women's characteristics as housing market customers. Analyses of factors such as age and 
the role of women in childbirth and expectations resulting from living conditions are also presented. Section 3 presents the general characteristics of Poland and Lithuania (for the cities of Olsztyn and Vilnius) and the characteristics of the profile of real estate market customers in both countries. Section 4 presents the results of the conducted research and a discussion of the obtained results. Section 5 presents conclusions drawn throughout this work.

\section{Theoretical Basis of the Research}

The tenure choice (ownership or tenancy) of residence is determined by many factors: economic [19,20], social [21-23], financial [24,25] and other factors [22]. The importance of this dilemma and the ways to solve it are determined inter alia by the decision-maker's age [26,27].

Young people with insufficient funds, when faced with a choice of whether to buy ownership of a dwelling unit and pay off the mortgage, often decide upon tenancy. A study conducted by Źróbek-Różańska and Szulc [15] demonstrated that young people not only want to live in an attractive location but also desire good access to their workplace or school and a good standard of interior finishing. Most researchers evaluated the preference of first-time homebuyers [28]. Studies of that type are generally conducted by developers wishing to know the relationship between the quality of the housing and property prices [29] and the price of the flat when it is selling under forced conditions [30].

However, there are few scientific papers concerning the effect of the customer's gender on the tenure choice [31-33]. Klak and Hey [34] examined women's access to the Jamaica National Housing Trust, created to finance housing for those most in need, and identified two gender biases. Varley $[35,36]$ emphasized the women-headed household percentage and gender and property formalization. Lambert et al. [37] analyzed women's position in the indoor spaces in which they live. To date, very few studies have evaluated the factors that determine the choice of housing market tenure and whether women have the final say in this matter. Brzezicka and Wiśniewski [38] analyzed whether women have a decisive say regarding the choice of the place of residence and make their decisions depending on their life situation: living alone, the future upbringing of their offspring and spending their old age. This partly results from nature, in which it is the female who often chooses the location for the nest, and humans are certainly an important component of this nature [39]. This phenomenon is often emphasized by real estate developers and marketing specialists.

The issue of making decisions concerning housing tenure choice will be considered in the initial part of this paper in terms of two basic factors: historical and mindset-based determinants, and demographic factors. The issue of women as housing market customers will also be discussed in more detail.

\subsection{Historical and Mindset-Based Determinants}

It is a commonly held belief that holding the right of ownership ensures a sense of security, life stability and mental comfort [40]. The purchase of real estate is often viewed as moving on to a new, better stage of life and a certain kind of step into adulthood [26]. Ownership, i.e., "this belongs to me", is deeply rooted in both Polish and Lithuanian mentality. In Poland, historical experiences have also had a profound impact on the different perception of these two different rights to a housing unit, i.e., ownership and tenancy. This fact was noted in an interview by sociologist Pęczak [41]. During the era of the partitions, Poland was under Prussian, Austrian and Russian rule for many centuries. An average Pole associates rent with leasing and a leaseholder is still regarded by many Poles as a person that is temporary, non-authentic and worse-off than the others. The same situation was in Lithuania. For this reason, owning a flat today is a manifestation of freeing oneself from the previous political control. Inhabitants of Central European countries who have experienced a centrally-planned economy and communism have a similar way of thinking. This is confirmed by statistical data (Figure 1). The countries with the highest percentage of people who own their flat include Romania, Lithuania, Croatia, North Macedonia and Slovakia [42]. According to data from 2019, private ownership in Lithuania reached $90.3 \%$ and in Poland it reached $83.4 \%$. 


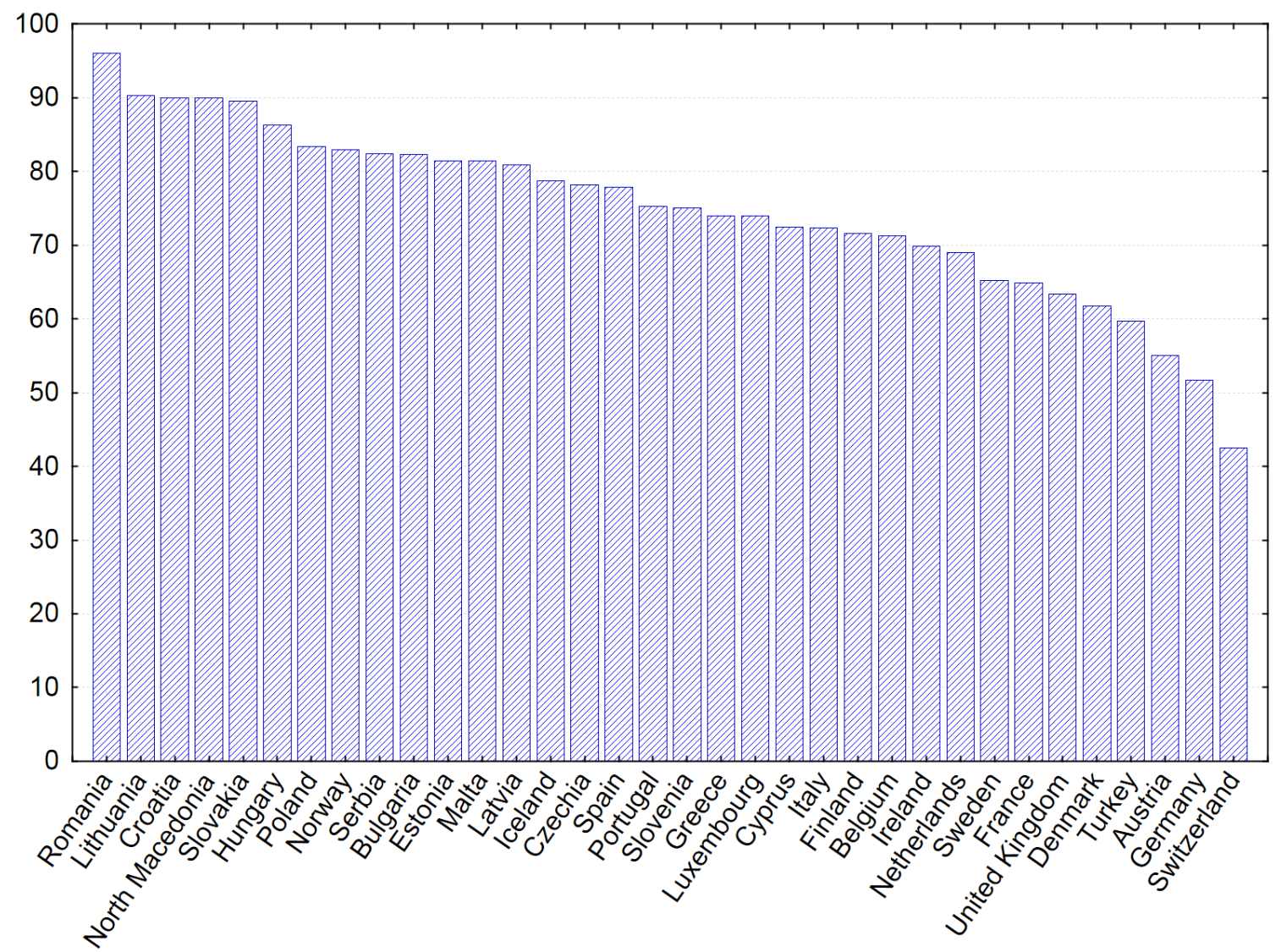

Figure 1. Share of population living in owner-occupied dwellings in the EU (\%). Source: own elaboration [42].

For many people, it is also important to have ownership of a flat as a way to ensure financial security in old age [23,43]. If one assumes that today's generation of 30-40-year-olds will have pensions lower by approximately $30 \%$ than people currently aged 65-70, Poles choose the ownership of real estate as a form of preserving capital and ensuring financial security for the future. The additional advantage of owning real estate is the possibility of bequeathing it over to one's own children in the future [44]. Poles are diligent consumers and, according to statistical data, in Poland $83.5 \%$ of Poles own flats or single-family homes [17]. Because the cost of rent in Poland is still high, people who are creditworthy prefer to be the owner of a flat, as the mortgage loan installment, including the rent and additional charges related to the purchase of real estate [45], is often lower than the rental payments for a flat.

\subsection{Demographic Factors}

The long-term equilibrium in the housing market is significantly affected by demographic factors, especially the rate of natural increase of the population and increases in the net migration trend [46,47]. Of all demographic factors, the age structure of the society is of priority importance. It is commonly believed that owning a flat indicates a higher social status of a particular person. It is emphasized that a chief income earner's age below 45 years may indicate that he/she is a tenant of the dwelling unit, while for an age over 45 years, the probability of ownership of an occupied flat increases significantly [46]. According to Młynarska [48], the real estate market is influenced by the age at which a woman gives birth to offspring. Changes initiated in 1990 resulted in a shift of women's peak fertility from the 20-24-year age group to the 25-34-year age group. As a consequence, the median age of women giving birth increased (from the beginning of this century) from 26.1 years in 2000 to 29.9 years in 2016. During this period, the average age of giving birth to the first child increased as well (from 23.7 
to 27.8 years, respectively) [17]. The data of Statistics Poland [49] show that in Poland, approximately $35 \%$ of women give birth to their first child at the age of 25-29 years; this group is closely followed by women aged 31-35 years, who account for approximately 31\%. According to the data of the Lithuanian Department of Statistics, in the first year of independence of Lithuania (in 1991), the highest number of women gave birth at the age of 22. The number of women giving birth at 30-40 years old since 2005 increased about 1.5-fold. The current average maternity age (women who have given birth) in Lithuania is about 29 years [50]. The relationship between parenthood and owning a dwelling unit was reported by Foryś [51]. According to Matysiak [21], 57\% of women who became pregnant with their first child live in their parents' home and 30\% reside in their own flat. A tendency to change the place of residence emerged in the following years. When the child reaches the age of 2-3 years, $42 \%$ of women reside in their own flat, while for the child aged over 3 years, $47 \%$ of women reside in their own flat. It was also demonstrated that the child's age had no effect on the actual renting of a flat, and the percentage of people renting a housing unit ranged from $11 \%$ to $13 \%$. On the other hand, the trend of moving into one's own flat is observed with an increase in family size.

According to the data of the Income and Living Conditions Survey, in 2011, most (90\%) families in Lithuania with children lived in their own single-family homes or flats. However, almost $40 \%$ of families said that maintaining a house is a very heavy burden, and only $9 \%$ of families did not feel this burden. In 2011, 61\% of families with children lived in flats (dwellings), 31\% lived in a single-family house and $7 \%$ lived in a semi-detached house [52]. Other reasons influencing the decision as to whether to purchase or rent a flat are indicated by Forlicz [53]; these include: (a) the passage of time (the result of aging and gaining experience); (b) changing the surroundings, including physical (the location), social (health status) and cultural conditions (a new system of values, etc.); (c) the effect of imitating other people; (d) the prestige effect (Veblen's paradox); (e) the "sour grapes" effect (undervaluing the goods one is not able to acquire, and overvaluing those which are easily accessible); and (f) the emergence of new goods or information on their existence (attractively priced, with attractive utility parameters).

\subsection{Women as Housing Market Customers}

Since the mid-19th century, women's activity in the areas previously reserved exclusively for men has been gradually increasing. Is the situation of the real estate market similar? Are women seizing the initiative and having a decisive say in this area as well? Decision-making in investment processes based on gender has been studied in relation to the willingness to take risks [54,55], to trade on the stock exchange [56] and engage in the housing market [57]. However, it should be noted that these studies do not directly analyze the gender issue in relation to the tenure decision. No broader scientific studies of this topic are available in the Polish literature on the subject. As mentioned before, the first attempts to analyze the significance of gender and age in the decision-making process in the real estate market were made in 2018 [38]. This may be because the real estate market and free trading in rights to real estate in Poland are relatively new compared to Western European countries. After the economic transformation in the 1990s, a number of changes took place in the field of real estate management. At that time, real estate companies modeled on enterprises operating in Western European countries and the United States began to emerge. It was mainly these companies that began to assess gender impact on purchasing real estate. Even though the main purpose of their analysis was to establish the principles of effectively promoting and selling real estate, they also considered women to be significant customers in the housing market. On the other hand, no symptoms of adaptation of built apartments by construction companies to women's tastes and needs were noted. There is also no information as to whether construction companies employ, for example, architects who know the needs of women when designing buildings. 


\section{Case Study-General Characteristics of the Research Objects}

\subsection{Description of the Study Structure}

A description of the structure of the study, including the specification of study stages and the methods applied to implement particular tasks, is presented in Figure 2.

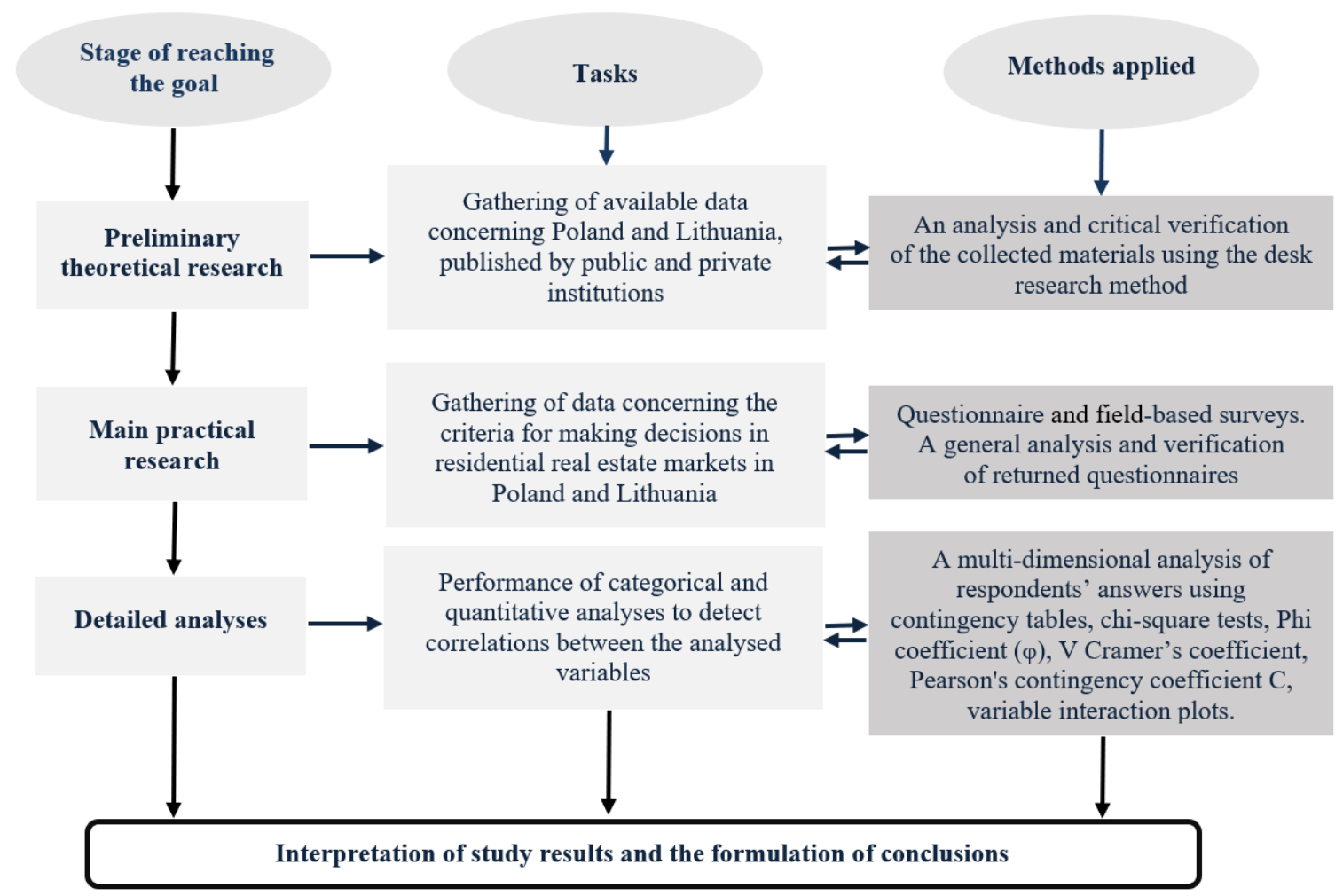

Figure 2. Diagram of the study organization.

The content of the subsequent chapters of this paper follows the above-mentioned research procedure.

\subsection{Poland and Lithuania-General Data and a Short Common History}

The research concerning women's importance in the housing market was conducted in Poland and Lithuania because these countries are now members of the European Union and have a common history. Figure 3 shows the location of Poland and Lithuania in Europe and the objects of the practical research (Olsztyn and Vilnius).

The close integration of Poland and Lithuania took place in 1569, when the so-called Union of Lublin was concluded, under which a common state emerged, named the Commonwealth of Two Nations until 1791. Further integration of Poland and Lithuania was interrupted by the partitions, as a result of which the common territories of these countries were separated and incorporated within the borders of three European powers (Austria, Prussia and Russia) until they regained independence in 1918. Unfortunately, after the end of the World War II in 1945, both countries were included into the block of socialist states dominated by the Union of Soviet Socialist Republics (USSR), with Lithuania making up one of those republics while Poland remained a dependent state. Those twists and turns in the history of both nations provided the inspiration to start comparative studies concerning the behaviors of the housing market customers in Poland and Lithuania, taking into account the role of women as an important determinant of the demand side of this market. It was expected that despite many years of historical, religious and cultural connections, important political events in the history of those countries could result in different cultural codes, which may include, for instance, a significantly different importance of women in those societies. As regards the Eastern European countries that 
underwent the transformation from a centrally-controlled economy to a free market economy in the 1990s, attention should be paid to the rapidly changing attitudes in post-socialist societies towards the perception of ownership rights and understanding the housing market. The introduction in the late 1990s of changes, such as ensuring freedom of economic activity and the protection of property rights and inheritance, influenced the development of the residential real estate market $[58,59]$. These favorable political and economic changes have an increasing impact on the possibility to choose the conditions of residence and the housing tenure.

Elderly people are burdened with the personal experience of a socialist economy, which discouraged ownership rights, including the private ownership of land, flats and houses. On the other hand, the younger part of society regards the right of ownership in the housing market as an ordinary social standard, which corresponds to the behavior of societies in Western European countries.

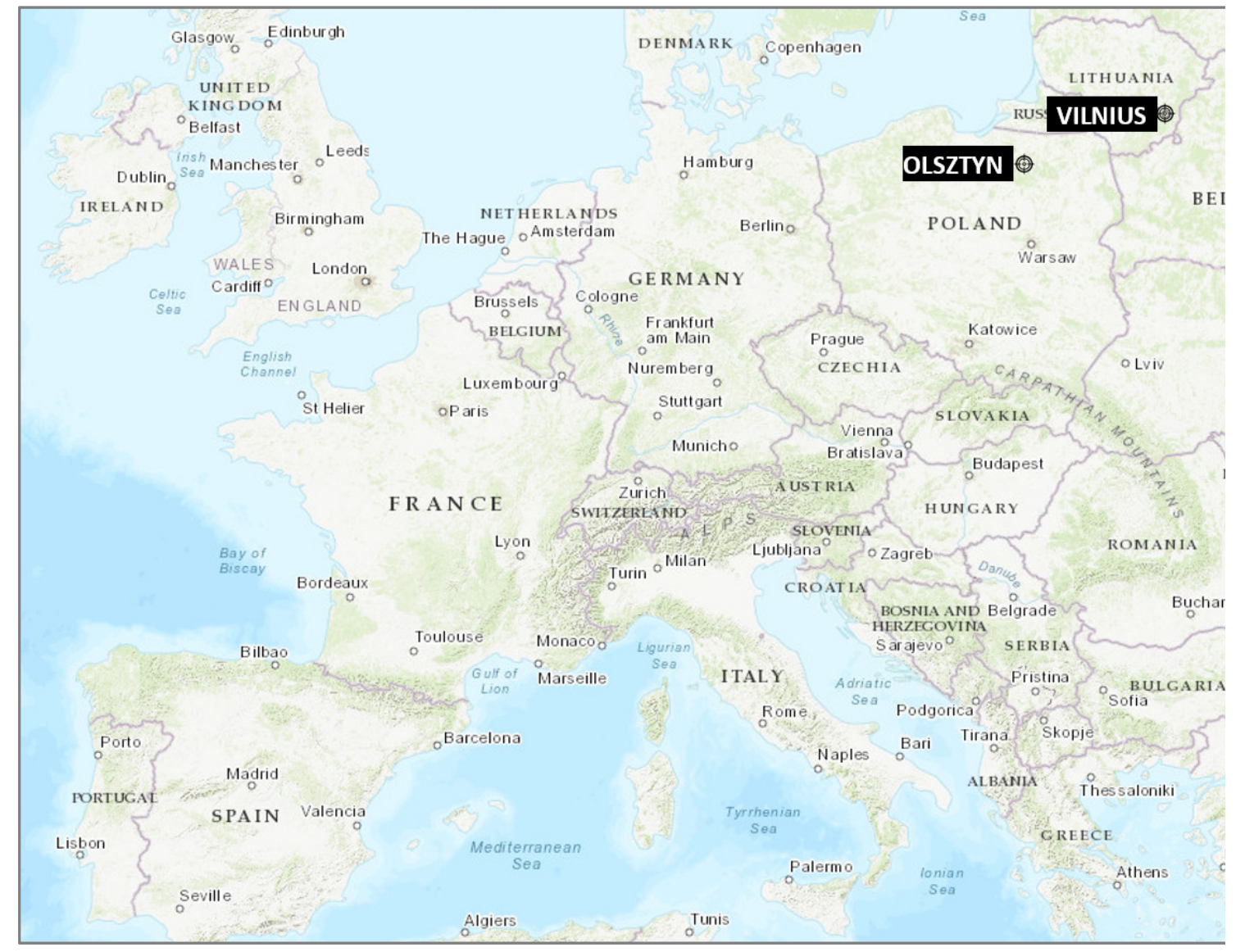

Figure 3. Location of Poland and Lithuania in Europe and the objects of the practical research.

As part of the preliminary research, in order to carry out comparative analyses of the preferences of flat purchasers/tenants in Poland and Lithuania, data were compiled that characterized both countries. Table 1 presents the basic information and data concerning the analyzed countries. 
Table 1. General political and socio-economic data of Poland and Lithuania.

\begin{tabular}{|c|c|c|}
\hline Kinds of Data & Poland (PL) & Lithuania (LT) \\
\hline General location and area & Europe/312,679 sq. km & Europe/65,300 sq. km \\
\hline Government & Parliamentary Republic & Unitary semi-presidential republic \\
\hline Member of the European Union & From 1 May 2004 & From 1 May 2004 \\
\hline Population & $38,432,992$ & $2,791,903$ \\
\hline \multicolumn{3}{|l|}{ Age structure of the population } \\
\hline $0-14$ years & $15.0 \%$ & $15.8 \%$ \\
\hline 15-64 years & $68.6 \%$ & $61.8 \%$ \\
\hline 65 years and more & $16.4 \%$ & $22.4 \%$ \\
\hline Women as $\%$ of the population & $52 \%$ & $53.9 \%$ \\
\hline The average size of flats & $\begin{array}{c}73.8 \mathrm{~m}^{2} \\
\text { in urban areas-64.5 } \mathrm{m}^{2}, \\
\text { in rural areas-93.1 } \mathrm{m}^{2}\end{array}$ & $\begin{array}{l}68 \mathrm{~m}^{2} \\
\text { in urban areas-62.1 } \mathrm{m}^{2} \text {, } \\
\text { in rural areas-79.9 } \mathrm{m}^{2} .\end{array}$ \\
\hline $\begin{array}{c}\text { Gross domestic product, } \\
\text { current prices in USD Billion } \\
\text { Dollars }\end{array}$ & GDP 571.32 & GDP 96.91 \\
\hline $\begin{array}{l}\text { Gross domestic product per capita, } \\
\text { current prices in USD }\end{array}$ & $\begin{array}{l}\text { GDP per capita } \\
13,811.66 \text { USD }\end{array}$ & $\begin{array}{l}\text { GDP per capita } \\
16,680.68 \text { USD }\end{array}$ \\
\hline Unemployment rate & $4.5 \%$ & $6.1 \%$ \\
\hline
\end{tabular}

\subsection{General Profile of Housing Market Customers}

In order to carry out detailed research on the real estate market and to provide a proper interpretation of the results of its analysis, it is important to indicate at least one customer profile for a given market segment. For the purposes of this paper, the profile of the housing market customer in Poland and Lithuania was prepared based on information from the banking area [61]; real estate brokers [62-65] and on interviews with experts in the field of housing development and mortgage counseling (Table 2). In Poland, ten interviews were conducted with mortgage bankers, eight interviews with real estate development companies and six interviews with experts from real estate agencies. At the same time in Lithuania, ten interviews were conducted with real estate market experts and six interviews with mortgage bankers.

As results from the profile of the housing market customer, women are more involved in real estate tenure. Such an opinion was expressed by real estate brokers from both examined countries. Entering into marriage or making a decision on living together and having children is an event that significantly affects housing tenure decisions. On the other hand, according to bank data analyses, married couples receive the majority of credits, and the real estate for which they are taking this credit is primarily a housing unit. This fact in many cases justifies the decision to purchase a flat.

Research conducted by a network of real estate agencies [65] shows various preferences of real estate agency website users. Below are some of the conclusions from conducted analyses. Flats are sought mainly by young women working their way up the professional career ladder $(47 \%$ of them are women aged from 26 to 35 years old). Women with an established professional position account for $21 \%$ (36-45 years of age), $13 \%$ (46-55 years of age) and 11\% (over 55 years of age) of flat seekers. Women under the age of 25 account for only a few percent of the total. The female respondents' answers also show that women are interested in commercial premises and building plots to a lesser extent than men. Research conducted by the Walczak [67] shows that the final decision on the purchase of real estate is taken by women $(63 \%)$. 
Table 2. Profile of Polish and Lithuanian clients of the housing market.

\begin{tabular}{|c|c|c|c|}
\hline Sources of Data & Type of Data & Polish Client & Lithuanian Client \\
\hline \multirow[t]{2}{*}{ Bank statistical analyses } & Age of borrowers & $\begin{array}{c}\text { Up to } 35 \text { years ( } 57.6 \% \text { share in the number of } \\
\text { mortgage loans). }\end{array}$ & $\begin{array}{l}25-34 \text { years ( } 60 \% \text { share in the } \\
\text { number of mortgage loans). }\end{array}$ \\
\hline & Aim of a mortgage & Flat purchase $(66 \%)$ & Flat purchase (58\%) \\
\hline $\begin{array}{l}\text { Direct interview- } \\
\text { bank advisers }\end{array}$ & Gender of person signing the loan agreement & $\begin{array}{l}\text { Joint ownership of statutory } \\
\text { marriage-together. } \\
\text { Single people-more often men; women } \\
\text { very rarely. }\end{array}$ & $\begin{array}{l}\text { Married couple-together. } \\
\text { Single-more often men }\end{array}$ \\
\hline \multirow{5}{*}{$\begin{array}{l}\text { Direct interview- } \\
\text { real estate agents }\end{array}$} & Gender of person signing an agency contract & $53 \%$ women & $45 \%$ women \\
\hline & $\begin{array}{l}\text { Gender of person having a decisive voice in } \\
\text { the selection of real estate }\end{array}$ & $90 \%$ women & $45 \%$ women \\
\hline & Gender of person looking for real estate & $47 \%$ women & $45 \%$ women \\
\hline & What right to real estate is acquired? & $\begin{array}{l}54 \% \text { women indicated the ownership of } \\
\text { real estate. }\end{array}$ & $\begin{array}{l}40 \% \text { of women indicated the } \\
\text { ownership of real estate. }\end{array}$ \\
\hline & Stage of life & $\begin{array}{l}\text { Young spouses make a decision together. } \\
\text { Mature families-the wife makes the } \\
\text { decision (men older than } 40 \text { years are more } \\
\text { involved in work outside the home). }\end{array}$ & $\begin{array}{c}\text { Young spouses make a decision } \\
\text { together. }\end{array}$ \\
\hline
\end{tabular}

Source: authors' own research based on interviews with experts and Dominium [66]; SEB [64]. 
In Lithuania, access to such detailed data is more difficult. Online publications more often refer to the issue of investing in the market in order to earn income from real estate. People in Lithuania would be much more satisfied with their life if they earned twice as much as they currently do, and the most attractive investment is real estate property, according to the latest survey of the Bank of Lithuania [68]. Real estate market specialists say that apartments for investment in Lithuania are more often chosen by women than men. As noted by the developers of small apartment projects in the capital, most of the apartments they sell are purchased on the initiative of women, who later purchased real estate used for rent. This trend also reflects deeper differences in financial behavior between women and men. According to a survey conducted by Barclays Bank, $49 \%$ of women name real estate as the best solution for investment. According to Fidelity's survey, the US dollar investments of women in the US brought $0.4 \%$ average higher financial returns than men's investments [69].

In summary, it may be concluded that demographic and social reasons, as well as the decisions taken by women, create the image of the housing market.

\subsection{The Cities Vilnius and Olsztyn as the Objects of Detailed Research}

Our practical studies involved customers of two local markets in those countries-Olsztyn in Poland and Vilnius in Lithuania. Olsztyn is the capital city of the province of Warmia and Mazury, the seat of local authorities and institutions, and is a main business, educational and cultural center. Vilnius is the capital city of Lithuania, the seat of municipal authorities of the Vilnius city and the surrounding region, and a large economic, cultural and academic center. Both cities are located within a distance of $500 \mathrm{~km}$ of each other. In view of the history of these cities, Vilnius is also the main center of Polish culture and science in Lithuania. Table 3 presents significant data concerning those research objects.

Table 3. General description of Olsztyn and Vilnius.

\begin{tabular}{ccc}
\hline Data Types & Olsztyn & Vilnius \\
\hline Total number of inhabitants, including: & 173,000 & 551,900 \\
women & $53.5 \%$ & $55 \%$ \\
men & $46.5 \%$ & $45 \%$ \\
\hline Households & $62 \%$ & $64 \%$ \\
multi-person households & $38 \%$ & $36 \%$ \\
one-person households & $17 \%$ & $16 \%$ \\
\hline Age structure of the population at the: & $67 \%$ \\
pre-working age & $22 \%$ & $17 \%$ \\
working age & 0.94 & 0.83 \\
\hline post-working age (retirees) & 3.06 \\
\hline Gross monthly income/monthly rent for a $45 \mathrm{~m}^{2}$ of a flat & 2.33 & \\
\hline Sonrce: authors' own research based on $[17,59]$.
\end{tabular}

All citizens of Poland and Lithuania are equal by law, regardless of their gender. Their rights are guaranteed in Poland (article 33) and in Lithuania (article 29) by the provisions of the Constitution. This also applies to holding various legal rights to real estate and the freedom of their use.

\section{Results of the Research and Discussion}

\subsection{Characteristics of Olsztyn and Vilnius Respondents}

A comparative study into the decisions taken in the residential market by households was conducted among respondents from Olsztyn (101 questionnaires) and Vilnius (84 questionnaires). In this study, a household is defined as either a one-person household, i.e., a person who makes provision for his or her own food and other essentials of living without combining with any other 
person to form a multi-person household; or a multi-person household, i.e., a group of two or more persons living together who make common provision for food and other essentials for living [70].

The questionnaires were drawn up in the respondents' national languages and made available from October to December 2019 on a specialized online platform. Twenty-five questions were formulated with different possibilities for providing answers, e.g., a choice of one or more suggested options or open questions. The survey questions were addressed to the target groups: public offices, private institutions and universities.

The aim was to assess the motives for the tenure decision and what were (or are) the significant reasons for changing the place of residence. The general characteristics of respondents are presented in Table 4.

Table 4. Characteristics of Polish (Olsztyn) and Lithuanian (Vilnius) respondents.

\begin{tabular}{|c|c|c|c|}
\hline Feature & Characteristic & Olsztyn & Vilnius \\
\hline \multirow{2}{*}{ Households } & Multi-person household & $79.2 \%$ & $57.1 \%$ \\
\hline & One-person household & $20.8 \%$ & $42.9 \%$ \\
\hline \multirow{2}{*}{ Sex } & Female & $58.4 \%$ & $61.9 \%$ \\
\hline & Male & $41.6 \%$ & $38.1 \%$ \\
\hline \multirow{4}{*}{ Age (in years) } & $<30$ & $9.9 \%$ & $41.7 \%$ \\
\hline & $31-45$ & $65.2 \%$ & $33.3 \%$ \\
\hline & $46-60$ & $11 \%$ & $22.6 \%$ \\
\hline & $61<$ & $13.9 \%$ & $2.4 \%$ \\
\hline \multirow{5}{*}{ Employment } & State sector & $58.4 \%$ & $31.0 \%$ \\
\hline & Private sector & $15.8 \%$ & $50.0 \%$ \\
\hline & Own business & $14.9 \%$ & $8.3 \%$ \\
\hline & Unemployed & $2.0 \%$ & $8.3 \%$ \\
\hline & Retirement & $8.9 \%$ & $2.4 \%$ \\
\hline \multirow{4}{*}{ Place of residence } & Voivodeship city & $57.4 \%$ & $95.2 \%$ \\
\hline & County city & $25.8 \%$ & $3.6 \%$ \\
\hline & Community & $6.9 \%$ & $0.0 \%$ \\
\hline & Village & $9.9 \%$ & $1.2 \%$ \\
\hline \multirow{4}{*}{$\begin{array}{l}\text { Satisfaction with the } \\
\text { current place of } \\
\text { residence }\end{array}$} & Definitely like & $43.4 \%$ & $40.5 \%$ \\
\hline & Like & $22.2 \%$ & $19.0 \%$ \\
\hline & Rather like & $18.2 \%$ & $9.5 \%$ \\
\hline & Want to change & $16.2 \%$ & $31.0 \%$ \\
\hline
\end{tabular}

Table 4 shows that women more often than men actively participated in the study, and consequently, they accounted for approximately $60 \%$ of the total number of respondents. Over $75 \%$ of respondents in both countries were under 45 years of age. For Polish respondents, over $65 \%$ were between 31 and 45 years old, while for Lithuanian respondents the proportion amounted to slightly over $33 \%$. The cause of this disproportion is a multi-person household (over $79 \%$ in Poland and over $57 \%$ in Lithuania). Consumer behavior is, to a large extent, determined by social relations with one's family and closest friends [71]. The study found that a one-person household (approximately $21 \%$ in Poland and approximately $43 \%$ in Lithuania) indicated different housing needs than a multi-person household.

A study of consumer behavior in the housing market should be based on answers provided by young or middle-aged people, to ensure that respondents represented the actual, and not potential, demand. High residential activity (ownership/sale/tenancy/rent) of respondents under 45 years of age results, inter alia, from:

- The willingness to confirm one's material status (the location in the social hierarchy, defined by the most valuable asset in the household, i.e., a house or a flat); 
- The birth of children (the need for increasing the flat's area);

- Occupational mobility (a choice between tenancy and ownership a flat).

The elderly respondents' answers concerning the reasons for changing their place of living in the future or making a real estate tenure decision did not realistically reflect considered future decisions in the housing market. As a rule, elderly people are not interested in changing their place of residence [72]. This was also confirmed by Cocco et al. [73] and Yogo [74] concerning the purchase of residential real estate by older people and changing their place of residence [75].

As regards the older people participating in the survey (aged over 60), they only accounted for $2.4 \%$ in Lithuania and $13.9 \%$ in Poland. The presented respondents' distribution in terms of age (Table 1 ) is appropriate for the aim of the study. The average age of respondents (44 years in Poland, and 36 years in Lithuania) reflects the high level of professional activity (approximately 90\%). An interesting fact is the Lithuanian respondents' dominant level of employment in the private sector (approximately $50 \%$ ) with an almost $60 \%$ level of employment in the public sector in Poland. Almost $70 \%$ of female Polish respondents are employed in state or local government institutions, which, as a rule, is regarded as a stable and safe form of employment; $10 \%$ work in the private sector and 3\% run their own business. The high rate of female respondents' employment in the public sector results from the fact that state and local administration (including state health care and education) is very expanded in Poland, and it reflects the general employment structure across Poland. On the other hand, over $58 \%$ of Lithuanian women work outside the public sector: $50 \%$ work in the private sector and over $8 \%$ run their own business. Detailed relationships between gender and the form of work activities are presented in Figure 4.

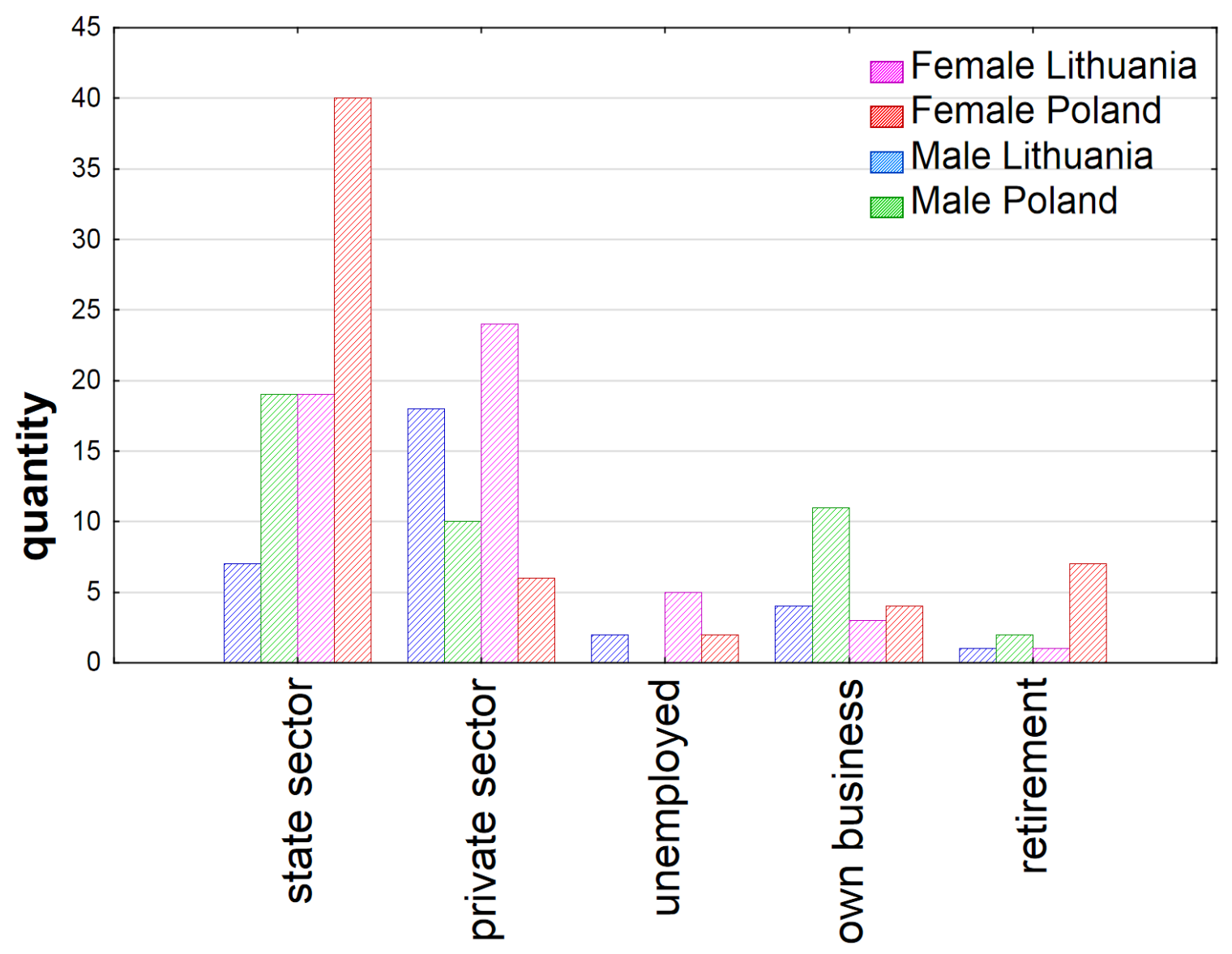

Figure 4. Multi-series bar chart of the relationship between gender and form of work activity. 
As a result, 31\% of respondents from Lithuania indicated a desire to change their present flat, compared to over $83 \%$ of respondents from Poland who indicated their satisfaction. Respondents from Poland and Lithuania also provided answers to the question concerning the main reason for the intention to change their flat in the future (Figure 5).

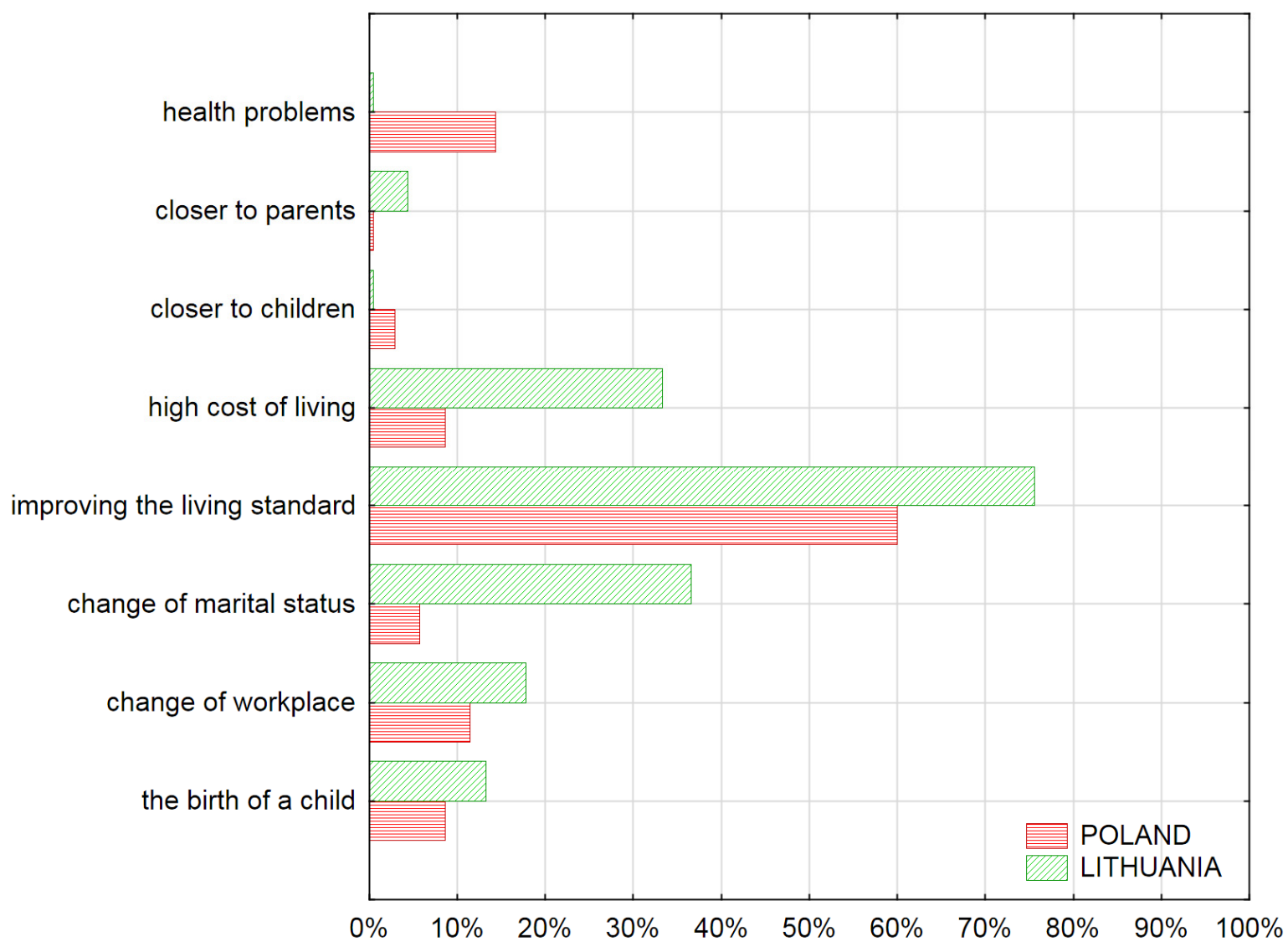

Figure 5. Reasons for the intention to change the flat.

The results based on answers provided by respondents from Poland and Lithuania (Figure 5) demonstrate that deciding to change the current place of residence is most significantly influenced by the need to improve its standard. The disproportion in marital status (Table 2) among the respondents from Poland and Lithuania is clearly noticeable in the indication of changing the marital status by Lithuanians (almost 40\%) being the second most important reason for searching for a new flat. Over 30\% of Lithuanian respondents indicate a high cost of living (high rent), compared to only $8 \%$ of respondents from Poland indicating this reason. However, Polish respondents indicate health problems (approximately 15\%) as a significant cause of changing the place of residence.

Since a significant proportion of respondents (approximately $84 \%$ in Poland and approximately $70 \%$ in Lithuania) are satisfied with the flat they own, respondents were asked to indicate the reasons for not being interested in changing their current place of residence (Figure 6).

For most respondents from the analyzed countries (over 60\%), the most important reason for not being interested in searching for a new flat was the distance to the workplace. Almost $40 \%$ of Poles and Lithuanians indicated the positive effect of proximity to health care facilities (hospitals and clinics). Financial issues were important to approximately $30 \%$ of respondents from Lithuania and $15 \%$ of respondents from Poland. 


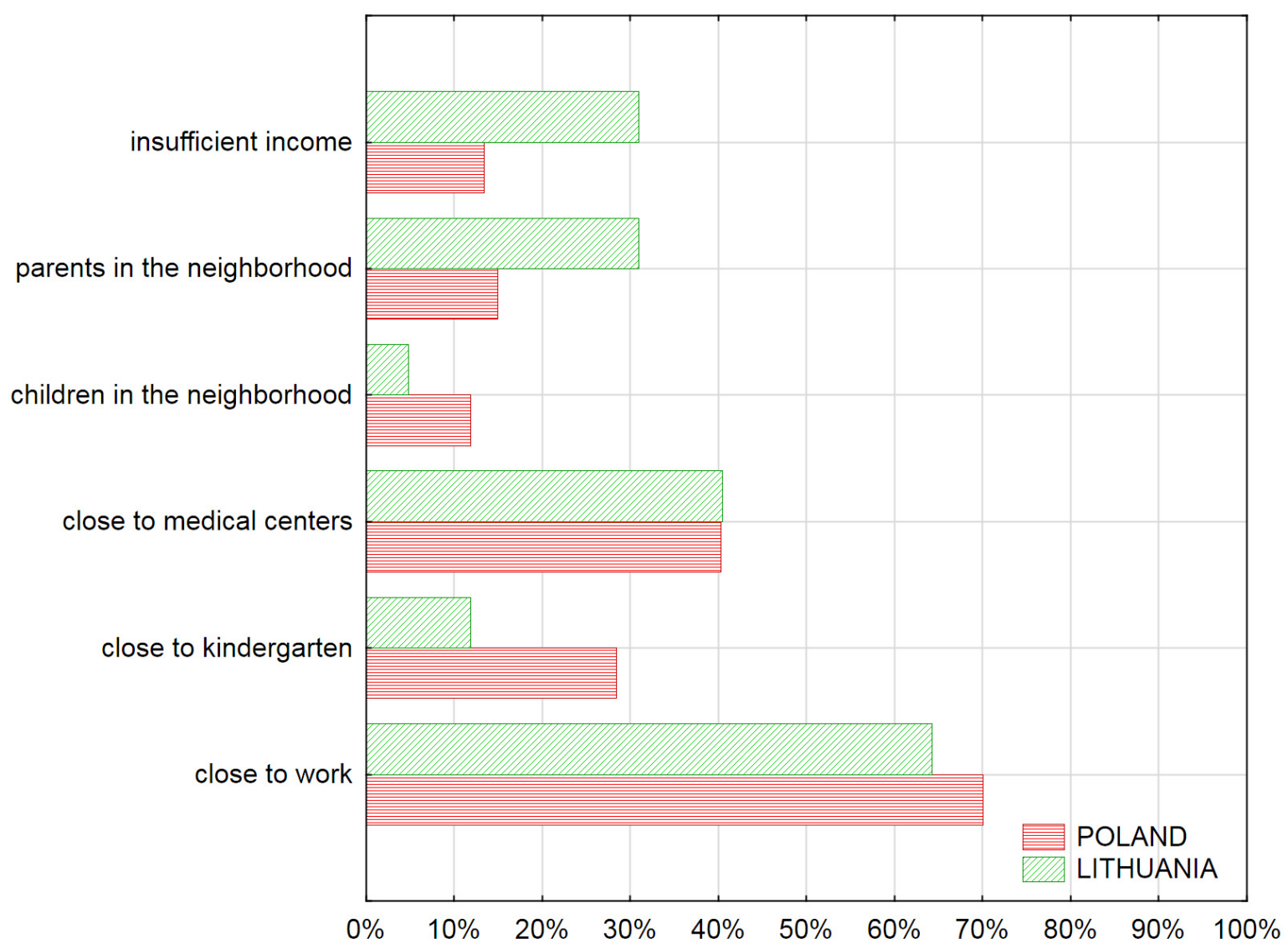

Figure 6. Reasons for not being interested in changing the flat in the future.

\subsection{Examination of Gender Impact on Housing Choice Decisions}

This study sought to verify the hypothesis of gender impact on decisions on the housing market. The demonstration of such a relationship using statistical measures is a significant condition for proceeding to the next stage of the study, i.e., determining gender impact on the housing market in Poland and Lithuania.

When answering a number of questions, respondents from both analyzed countries were asked to address the following issues:

- What right do they have to their currently inhabited real estate (ownership/tenancy)?

- Who has had the decisive say as regards the change of flat?

- Whether the next residential real estate will be owned or tenanted.

To this end, a multi-dimensional analysis of answers provided by all respondents included in contingency tables (crosstabs) was conducted. These tables enable the testing of the statistical significance of categorical variables and their interactions in the form of a log-linear analysis. Contingency tables [76-78] are a tool to describe categorical data involving the distribution of two or more segmentation variables. The result of the segmentation process is a matrix in which each cell indicates the number or frequency of the occurrence of analyzed attributes defined by specific variable values. Log-linear analysis $[79,80]$ is based on the maximum likelihood estimation method and examines the independence and interactions between categorical variables. In this method, any significant deviations in the numbers observed in the analyzed population from the expected results indicate the existence of relationships between these variables. In contingency (four-fold) tables, a statistically significant relationship is verified using a chi-square independence test. In this test, the null hypothesis assumes no relationships between the analyzed variables, while the alternative hypothesis confirms the occurrence of such a relationship. On the other hand, the strength between 
variables can be determined by calculating the Phi coefficient $(\phi)$, V Cramer's coefficient or Pearson's contingency coefficient $C$.

Table 5 presents the basic statistics for the conducted calculations without separating respondents based on gender, as the assumed effect was the confirmation of gender significance as one of the analyzed variables.

Table 5. Main statistics for the conducted calculations in contingency tables.

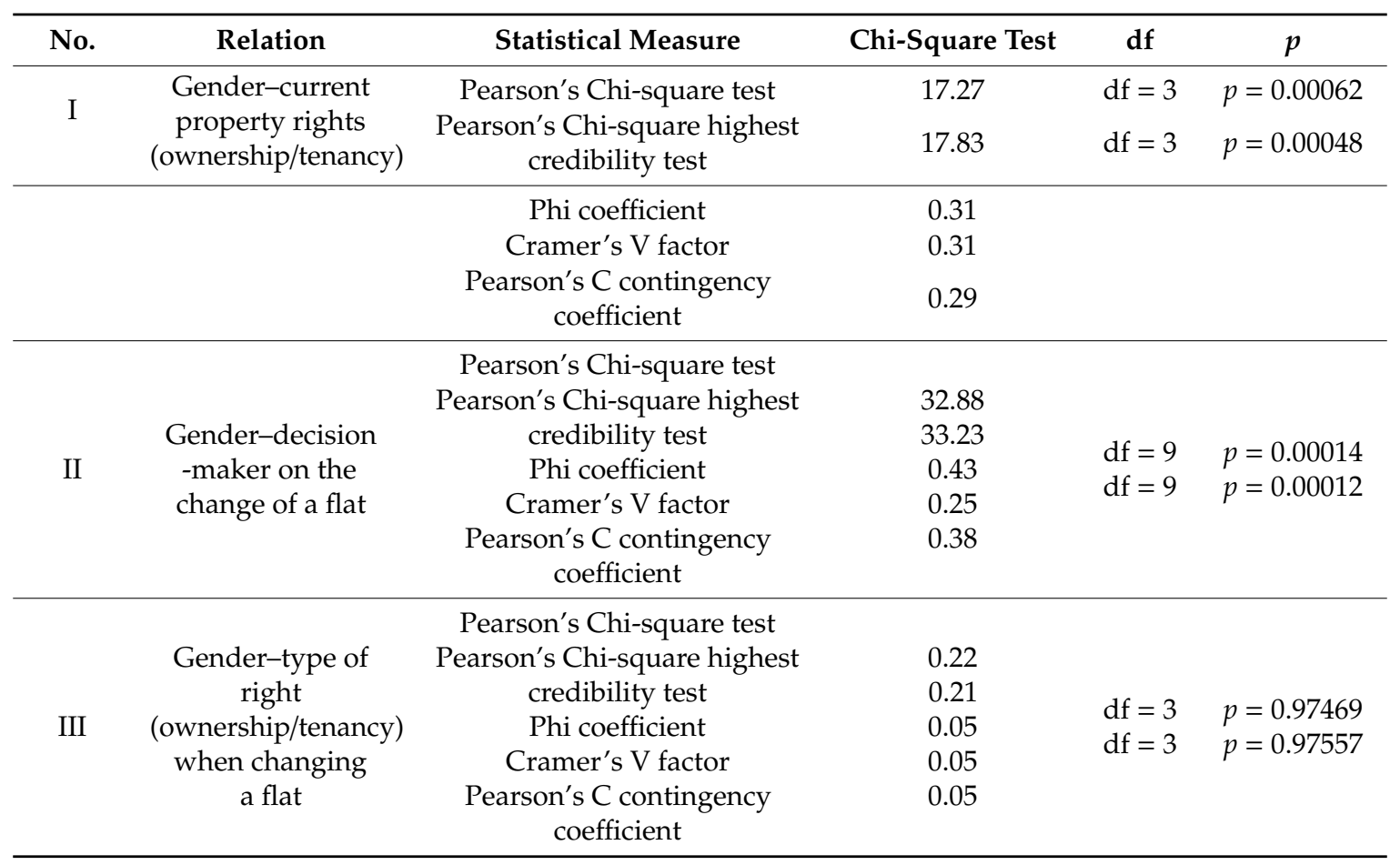

For relationships I and II (Table 5), the values of Pearson's chi-square test (17.27 and 32.88, respectively) and the maximum likelihood chi-square test (17.83 and 33.23, respectively) as well as the $p$-values (statistical significance at a level of $p<0.0001$ ) allow the null hypothesis to be rejected and, consequently, enable the demonstration of a significant relationship between the analyzed variables. This implies that there is a statistical relationship between gender (without distinguishing its types) and the variable related to the right to the flat held. At the same time, the conducted calculations demonstrated a significant relationship between gender and the decision-maker variable, which explained who influenced the decision on changing flat (inter alia, a jointly made decision or the partner's decision). Other statistical measures, i.e., Phi coefficient ( $\phi)$, V Cramer's coefficient or Pearson's contingency coefficient $C$ not only enable the determination of an actual significant relationship between variables but also measure the strength of the relationship between these variables. For each of these coefficients, the closer the coefficient value is to 1 within the $[0,1]$ range, the stronger the analyzed relationship is (for the coefficient $\phi$ the $[-1,1]$ range). For relationships I and II, the values of the obtained coefficients were at the level of average or relatively weak relationships ( 0.31 and 0.25 , respectively). For relationship III, all statistics confirmed the null hypothesis of no relationships between the analyzed variables $(p=0.97)$.

The confirmation of gender significance for relations I and II (Table 5) enables moving on to the next stage of the study, which involves taking into account the differences between women's and men's answers and the respondent's country of residence. Figures 7 and 8 present the plots of variable interactions between gender and the choice of a specific right to residential real estate (ownership/tenancy) as well as between gender and the decision-maker as regards changing flat. 


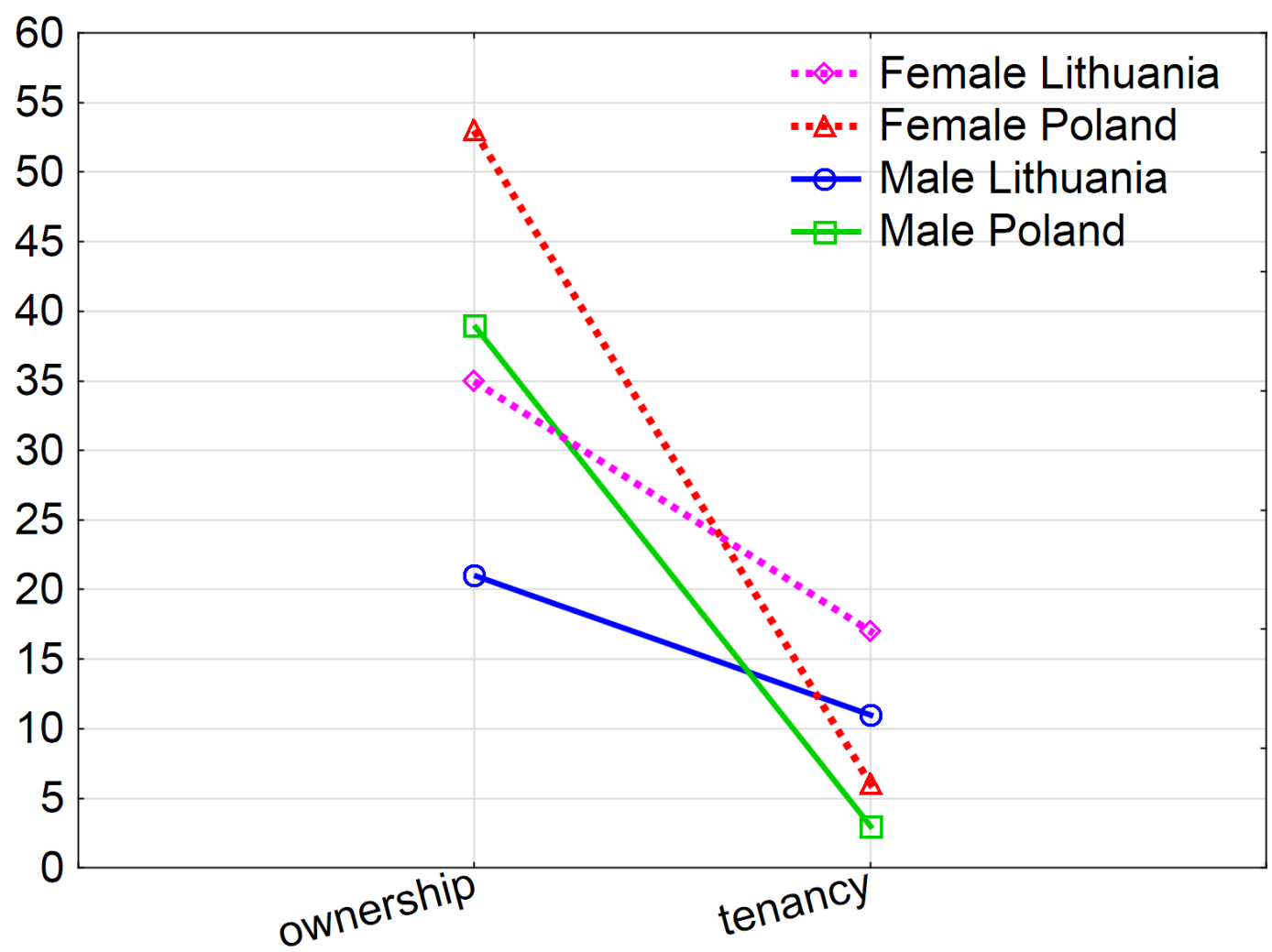

Figure 7. Interactions between gender and the current tenure of a flat.

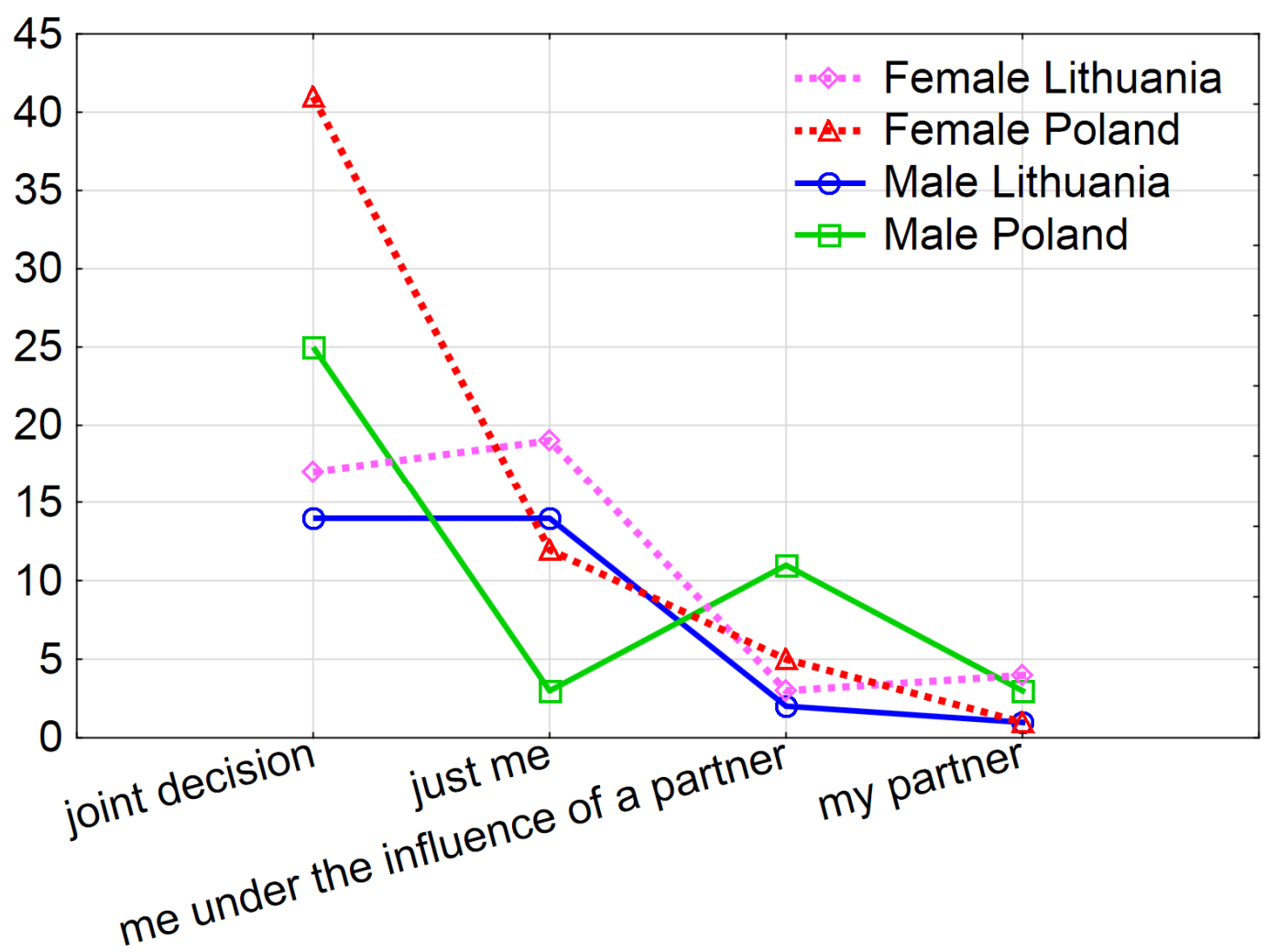

Figure 8. Interactions between gender and decision to change a flat.

Figure 7 shows the relationship between gender and the previously selected (currently owned) type of right to premises. Respondents from Poland prefer, to a small extent, tenancy as the right of 
possession of a flat, while respondents from Lithuania regard tenancy as an alternative to holding the right of ownership of a flat. Generally, however, in both countries, irrespective of gender, the dominant form of possession of real estate is ownership. The interaction analysis presented in Figure 8 shows that on the housing market, decisions on the intention to change housing are mostly taken jointly (by women and men) in the surveyed households. This may be due to a sense of responsibility for the family one already has or for the future offspring, where an important issue is the sense of residential security offered by the right of ownership of a flat. Only an insignificantly small group of men indicated making an independent decision, which particularly applies to respondents from Poland. The high number of respondents' answers stating that they made a decision while influenced by the partner indicates that Polish men, as a rule, await proposals from their partners. Women generally exhibit greater decision-making autonomy in this regard than men, with Lithuanian women independently make such decisions significantly more often than female respondents from Poland.

The respondents who decided to change their flat also indicated the importance of the following factors on their decisions: the birth of a child, change of workplace, change of marital status and the desire to improve the living standard (Figure 9).

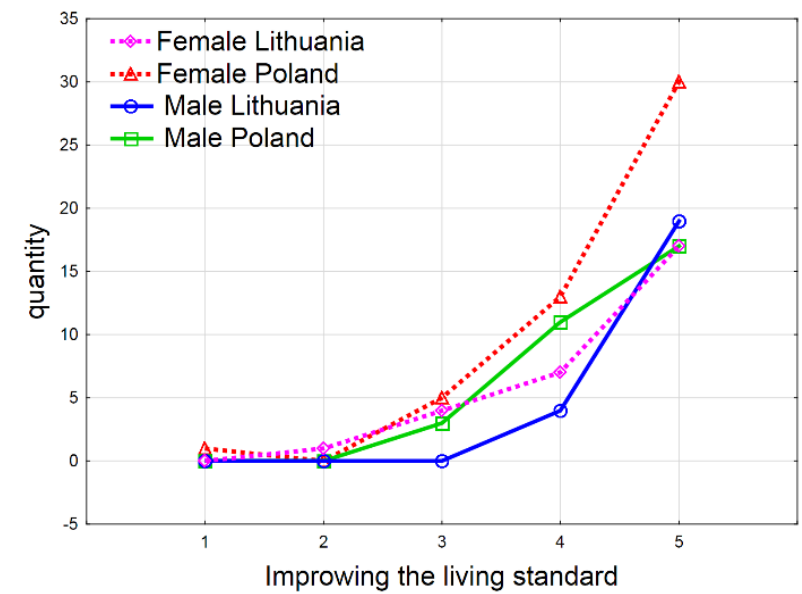

(a)

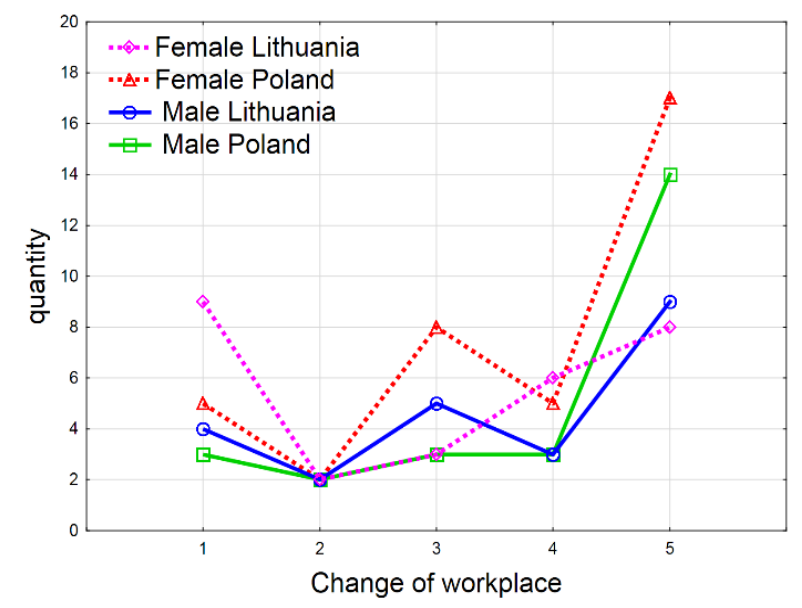

(c)

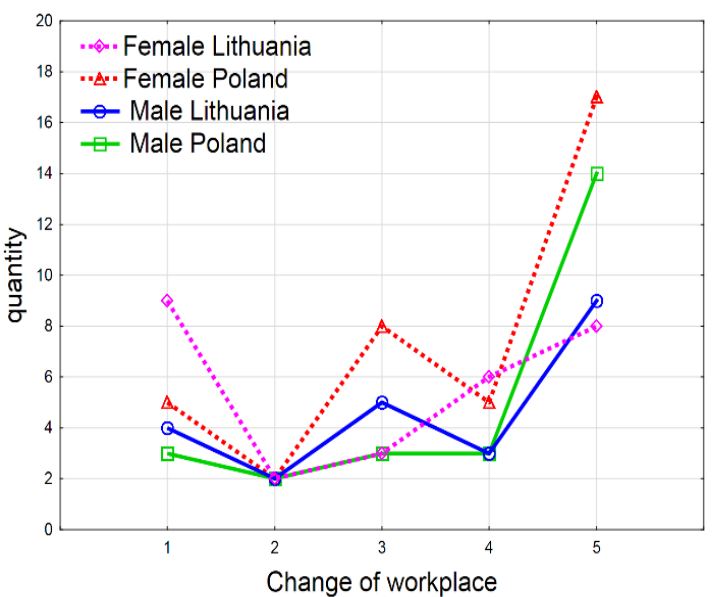

(b)

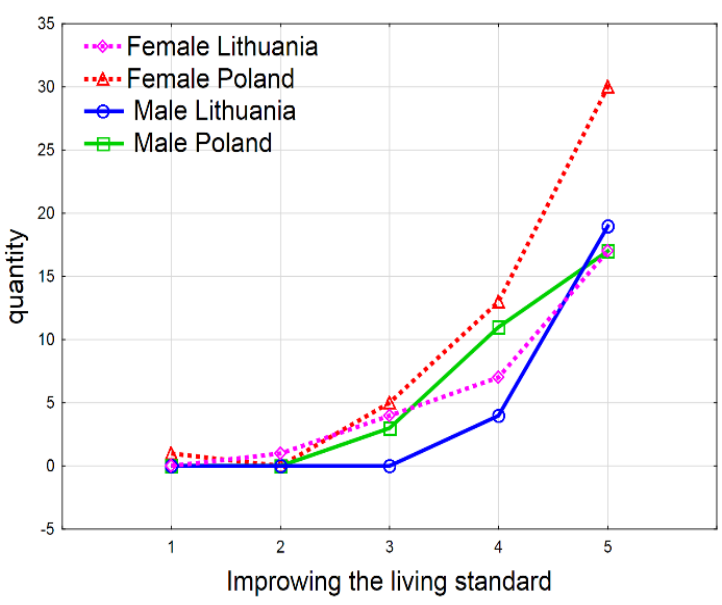

(d)

Figure 9. Factors determining the change of a flat according to the respondents: (a) the birth of a child; (b) change of workplace; (c) change of marital status; (d) improving the living standard.

The birth of a child (Figure 9a) is an important reason for changing the flat for most householders from Poland and Lithuania. The study adopted a 5-point Likert Scale of factor significance (including unimportant, slightly important, moderately important, important and very important). 
Approximately $65 \%$ of Polish female respondents indicated the highest level in the applied scale (very important) compared to such an indication made by only $45 \%$ of Lithuanian women who, at the same time, regarded (approximately 30\%) the birth of a child as an unimportant factor in changing the place of residence. The division of the adopted scale into 2 groups:

- The birth of a child: significant (scale—very important, important, moderately important);

- The birth of a child: not important (scale—slightly important, unimportant);

enables the determination of the general tendency in the behavior of men and women from both countries. Approximately $95 \%$ of women and men from Poland regard the birth of a child as a significant factor in changing the flat, which indicates a high similarity between both genders in this regard. A large disproportion is observed in Lithuania, as $83 \%$ of men and only $66 \%$ of women regard this factor as important. Based on the example of another variable interaction plot (Figure $9 \mathrm{~b}$ ), the high proportionality of respondent answers can be indicated more within the nationality than the sex difference. Polish respondents, both women and men, mostly considered a change of workplace as the most significant reason for changing a flat. This probably results from the low acceptance of tenancy by Polish society as a form of possession of residential premises for the period of workplace change. What is interesting is the fact that this feature is of low importance for a significant part of Lithuanian women. The dominant role of women in making decisions in the housing market can be confirmed by the results of analyses presented in Figure 9c, examining the effect of the marital status change on housing needs. Almost $70 \%$ of women from Poland indicated that a change of marital status has the most significant effect on the decision concerning the present place of residence. Therefore, the conclusion can be drawn that, after getting married, women strive towards common living in a new flat and are the more active side when making decisions in this matter (which is confirmed by the results of variable interaction plots in Figure $9 \mathrm{a}$ and the customer profile in Table 4 . At the same time, women and men from Lithuania had very similar opinions in this matter. As regards the significance of improving the housing standard as a reason for changing the flat (Figure 9d), only $2 \%$ of women from Poland and 3\% of women from Lithuania did not regard this factor to be important. Almost $100 \%$ of men from Lithuania (scale-very important, important) indicated the standard of living as an important element of decision-making in the housing market.

\section{Remarks and Conclusions}

The main purpose of the research was to investigate whether women have a significant role in decision-making in the housing market. After an analysis of existing theoretical views on the role of women in the housing market, a survey was conducted among respondents from Poland and Lithuania. The obtained responses were subjected to a multi-dimensional categorical and quantitative analysis. The analysis results, conducted using chi-square tests and the p-value, confirmed the occurrence of a significant statistical correlation between gender and the form of real estate acquisition (purchase or rent) and between gender and making a decision on changing a flat. The other statistical measures, i.e., Phi coefficient $(\phi), \mathrm{V}$ Cramer's coefficient and Pearson's contingency coefficient $C$ confirmed the occurrence of an average or relatively weak correlation between the analyzed relations.

The vast majority of Vilnius (Lithuanian) respondents (approximately 83\%) live in multi-family blocks of flats and approximately $58 \%$ of Olsztyn (Polish) respondents live in a single-family house. Due to this fact, respondents from Lithuania are much more willing to change their current place of residence. The results based on answers provided by respondents from Poland and Lithuania demonstrated that the most important reasons for the willingness to change the current place of residence was the need to improve the standard of living, a change in marital status and the high cost of tenanted flats (high rents) in Lithuania. Due to insufficient funds, approximately $30 \%$ of households from Lithuania and 15\% of households from Poland were not considering changing their flat.

It should be stressed that field research did confirm the predominance of a willingness to have ownership right of a flat over tenancy. Such preferences are quite clearly emphasized in the 
literature. Respondents from Poland prefer, only to a small extent, tenancy as the right of possession of flat, while respondents from Lithuania regard tenancy as an alternative to holding ownership of a flat. Women generally exhibit greater decision-making autonomy as regards housing issues than men, with Lithuanian women doing this much more often than female respondents from Poland. These results confirm the noticeable advantageous role of women in the housing market. It should be noted, however, that this role is not decidedly dominant. This is because the analysis of interactions showed that, in this market, joint decision-making (by women and men) prevails in changing flats in both considered objects. At the same time, this means that common cultural elements and a similar mentality shaped by historical conditions have a significant impact on the perception of real estate and decision-making in the real estate market.

This conclusion can be treated as a cognitive value of the conducted research. Although the number of respondents' answers was not very large, the results of the correlations could be useful for many entities, because they were additionally supplemented and confronted with the other existing sources of information and obtained at the time from interviews with experts from the local housing markets. An identification of factors affecting the choice of the tenure of flats by women and men can be used for more insightful and accurate decision-making in the field of housing policy and sustainable development. One of its instruments may be the identification of the priority tasks that need to be undertaken to create a more "fitting to needs" housing policy.

The results of the conducted analysis broaden the knowledge concerning the functioning of the housing market and may support the implementation of the pro-social and pro-sustainable spatial development policy of the given territorial unit. They may also contribute to a more sustainable development of the enterprises in the housing construction sector. This is an important issue in a situation of strong competition between "providers" of flats and the introduction of the idea of competition between them and the social environment. Due to the fact that clients of the housing market more and more often make their choice depending on the trust and position of the developer, some developers are joining programs run by public relations agencies. In these activities, they perceive the possibility of increasing a potential client's interest in their offer [81]. They also cooperate with consulting companies offering assistance in the planning process, investment implementation, consultancy and detailed analyses of local markets. These activities are part of the general term "sustainable construction", which is commonly understood as the design, construction and operation of building structures with a view to reducing their harmful effects on the natural environment while ensuring comfort and a high quality of life for their users [82,83]. Kalinowska-Sołtys [82] points out, among others, that in order for an architect to create a well-functioning, durable building, the cooperation of many participants of the investment process that are aware of a common goal is needed. This goal should be design solutions that will bring the largest ecological, economic and social benefits for planned investments. However, cooperation between construction companies and future buyers of dwellings is still not noticeable when taking into account their gender. This may be because the cooperation of enterprises in building their innovation potential in a manner more broadly suited to various social groups and their tastes is a relatively new form of cooperation in the studied countries [84].

Therefore, the answer to the question asked in the title of the article is affirmative. In addition, it was confirmed that women generally exhibit greater decision-making autonomy in final decisions regarding housing as a place to live for their family. In order to examine the extent of this advantage, more households should be included in further studies. The topics discussed in the article may become an inspiration for further research on the role of women in sustainable development, not only of the housing market, but also of the commercial real estate market.

Author Contributions: Conceptualization, S.Ź., E.Z.; methodology, S.Ź., E.Z., M.B., N.L.; visualization, M.B.; formal analysis, investigation, M.B., S.Ź., N.L.; resources, S.Ź., E.Z., M.B.; data curation, M.B.; writing-original draft preparation S.Ź., E.Z., M.B., N.L.; writing—review and editing S.Ź., E.Z., M.B., N.L. All authors have read and agreed to the published version of the manuscript. 
Funding: This work was supported by the National Science Centre [grant number 2019/33/B/HS4/00072].

Acknowledgments: The authors express sincere gratitude to the journal editor and the anonymous reviewers who spent their valuable time to provide constructive comments and assistance to improve the quality of this paper.

Conflicts of Interest: The authors declare no conflict of interest.

\section{References}

1. United Nations. Transforming Our World: The 2030 Agenda for Sustainable Development. Available online: https://www.un.org/ga/search/view_doc.asp?symbol=A/RES/70/1\&Lang=E (accessed on 20 March 2020).

2. World Health Organization. Housing and Health Guidelines. Available online: https:/apps.who.int/iris/ bitstream/handle/10665/276001/9789241550376-eng.pdf?ua=1 (accessed on 15 May 2019).

3. Case, K.E.; Quigley, J.M.; Shiller, R.J. Comparing Wealth Effects: The Stock Market versus the Housing Market. Adv. Macroecon. 2005, 5, 1235. [CrossRef]

4. Lis, P. Wahania Cykliczne Rynków Mieszkaniowych. Aspekty Teoretyczne i Praktyczne; Adam Marszałek: Torun, Poland, 2012; ISBN 978-83-7780-446-9.

5. Galster, G. William Grigsby and the Analysis of Housing Sub-Markets and Filtering. Urban Stud. 1996, 33, 1797-1805. [CrossRef]

6. Nykiel, L. Mieszkania Na Wynajem Jako Warunek Rozwoju Rynku Mieszkaniowego. Stud. Mater. Tow. Nauk. Nieruchom. 2012, 20, 95-110.

7. Renigier-Biłozor, M.; Biłozor, A.; Wisniewski, R. Rating Engineering of Real Estate Markets as the Condition of Urban Areas Assessment. Land Use Policy 2017, 61, 511-525. [CrossRef]

8. Protopopova, A. Effects of Sheltering on Physiology, Immune Function, Behavior, and the Welfare of Dogs. Physiol. Behav. 2016, 159, 95-103. [CrossRef]

9. Moguerane, K. A Home of One's Own: Women and Home Ownership in the Borderlands of Post-Apartheid South Africa and Lesotho. Can. J. Afr. Stud. Can. Études Afr. 2018, 52, 139-157. [CrossRef]

10. Museus, S.D.; Yi, V.; Saelua, N. The Impact of Culturally Engaging Campus Environments on Sense of Belonging. Rev. High. Educ. 2017, 40, 187-215. [CrossRef]

11. Dovie, D.A. Assessment of How House Ownership Shapes Health Outcomes in Urban Ghana. Societies 2019, 9, 43. [CrossRef]

12. Leckie, S. Housing as a Human Right. Environ. Urban. 1989, 1, 90-108. [CrossRef]

13. Trojanek, R. Determinanty Wahań Cen Na Rynku Mieszkaniowym. Stud. Mater. Tow. Nauk. Nieruchom. 2008, 16, 85-97.

14. Głuszak, M.; Małkowska, A. Preferencje Mieszkaniowe Młodych Najemców Lokali Mieszkalnych w Krakowie. Świat Nieruchom. 2017, 2, 39-44.

15. Źróbek-Różańska, A.; Szulc, L. Over a Million Student Tenants in Poland. Analysis of Preferences. Real Estate Manag. Valuat. 2018, 26, 104-113. [CrossRef]

16. Dziworska, K. Rynek Najmu Mieszkań-Współczesne Dylematy. Zarz. Finans. 2017, 15, 41-50.

17. GUS; CSO. Gospodarka Mieszkaniowa w 2016 r. Available online: https://stat.gov.pl/obszary-tematyczne/ infrastruktura-komunalna-nieruchomosci/nieruchomosci-budynki-infrastruktura-komunalna/gospodarkamieszkaniowa-w-2016-r-,13,12.html (accessed on 2 November 2019).

18. Statistics Lithuania. Statistical Yearbook of Lithuania (Edition 2019). Available online: https://osp.stat.gov.lt/ lietuvos-statistikos-metrastis/lsm-2019/gyventojai-ir-socialine-statistika/bustas (accessed on 29 April 2020).

19. Himmelberg, C.; Mayer, C.; Sinai, T. Assessing High House Prices: Bubbles, Fundamentals and Misperceptions. J. Econ. Perspect. 2005, 19, 67-92. [CrossRef]

20. Mizuno, M.; Tabner, I.T. The Margin of Safety and Turning Points in House Prices: Observations from Three Developed Markets. Financ. Anal. J. 2011, 67, 76-93. [CrossRef]

21. Matysiak, A. Posiadanie Własnego Mieszkania a Rodzicielstwo w Polsce. Stud. Demogr. 2011, 1, 37-55.

22. Mulder, C.H. Home-Ownership and Family Formation. J. Hous. Built Environ. 2006, 21, 281-298. [CrossRef]

23. Vignoli, D.; Rinesi, F.; Mussino, E. A Home to Plan the First Child? Fertility Intentions and Housing Conditions in Italy. Popul. Space Place 2013, 19, 60-71. [CrossRef]

24. Scanlon, K.; Whitehead, C.; Pichler-Milanović, N.; Cirman, A. International Trends in Housing Tenure and Mortgage Finance; London School of Economics: London, UK, 2004. 
25. Scanlon, H.; Whitehead, C. Housing Tenure and Mortgage Systems: A Survey of Nineteen Countries. In Housing Policy in the United States. An Introduction; Schwartz, A.F., Ed.; Routledge: New York, NY, USA, 2004.

26. Ineichen, B. The Housing Decisions of Young People. Br. J. Sociol. 1981, 32, 252-258. [CrossRef]

27. Hu, X. Portfolio Choices for Homeowners. J. Urban Econ. 2005, 58, 114-136. [CrossRef]

28. Lepkova, N.; Butkiene, E.; Bełej, M. Study of Customer Satisfaction with Living Conditions in New Apartment Buildings. Real Estate Manag. Valuat. 2016, 24, 52-70. [CrossRef]

29. Źróbek, S.; Trojanek, M.; Źróbek-Sokolnik, A.; Trojanek, R. The Influence of Environmental Factors on Property Buyers' Choice of Residential Location in Poland. J. Int. Stud. 2015, 7, 163-173.

30. Renigier-Biłozor, M.; Walacik, M.; Źróbek, S.; d'Amato, M. Forced Sale Discount on Property Market-How to Assess It? Land Use Policy 2018, 78, 104-115. [CrossRef]

31. Munro, M.; Smith, S.J. Gender and Housing: Broadening the Debate. Hous. Stud. 1989, 4, 3-17. [CrossRef]

32. Ling, R.D. Gender, Class and Home Ownership: Placing the Connections. Hous. Stud. 1998, 13, 471-486. [CrossRef]

33. Lee, C.-C.; Ho, Y.-M.; Chiu, H.-Y. Role of Personal Conditions, Housing Properties, Private Loans, and Housing Tenure Choice. Habitat Int. 2016, 53, 301-311. [CrossRef]

34. Klak, T.H.; Hey, J.K. Gender and State Bias in Jamaican Housing Programs. World Dev. 1992, 20, $213-227$. [CrossRef]

35. Varley, A. Women Heading Households: Some More Equal than Others? World Dev. 1996, 24, 505-520. [CrossRef]

36. Varley, A. Gender and Property Formalization: Conventional and Alternative Approaches. World Dev. 2007, 35, 1739-1753. [CrossRef]

37. Lambert, A.; Dietrich-Ragon, P.; Bonvalet, C. De Introduction Nouvelles Questions Pour un Vieil Objet. Monde Privé Femmes Genre Habitat Dans Soc. Fr. 2018, 3, 27.

38. Brzezicka, J.; Wisniewski, R. Znaczenie Płci i Wieku w Procesie Decyzyjnym Na Rynku Nieruchomości. Acta Sci. Pol. Adm. Locorum 2018, 17. [CrossRef]

39. Kamel, S.J.; Mrosovsky, N. Repeatability of Nesting Preferences in the Hawksbill Sea Turtle, Eretmochelys Imbricata, and Their Fitness Consequences. Anim. Behav. 2005, 70, 819-828. [CrossRef]

40. Avey, J.B.; Avolio, B.J.; Crossley, C.D.; Luthans, F. Psychological Ownership: Theoretical Extensions, Measurement and Relation to Work Outcomes. J. Organ. Behav. Int. J. Ind. Occup. Organ. Psychol. Behav. 2009, 30, 173-191. [CrossRef]

41. Pęczak, M. Kupić czy Wynająć Mieszkanie? Available online: http://mdmgdansk.pl/kredyty-i-finansowanie/ kupic-czy-wynajac-mieszkanie-co-sie-bardziej-oplaca.html (accessed on 20 August 2019).

42. Eurostat. Share of Population Living in Owner-Occupied Dwellings in the EU Members. Available online: https://ec.europa.eu/eurostat/documents/4187653/7825811/IMG+graph+1+News+Housing+ conditions.png/b0713af5-87dc-4edd-8abc-2a27d5340562?t=1508844372862 (accessed on 15 March 2019).

43. Megbolugbe, I.F.; Linneman, P.D. Home Ownership. Urban Stud. 1993, 30, 659-682. [CrossRef]

44. Brzezicka, J.; Wisniewski, R.; Figurska, M. Disequilibrium in the Real Estate Market: Evidence from Poland. Land Use Policy 2018, 78, 515-531. [CrossRef]

45. Manzhynski, S.; Źróbek, S.; Batura, O.; Zysk, E. Why the Market Value of Residential Premises and the Costs of Its Purchase Differ: The Examples of Belarus and Poland. Land Use Policy 2018, 71, 530-539. [CrossRef]

46. Andrews, D.; Sánchez, A.C. Drivers of Homeownership Rates in Selected OECD Countries. OECD Econ. Dep. Work. Pap. 2011, 849. [CrossRef]

47. De Boer, R.; Bitetti, R. A Revival of the Private Rental Sector of the Housing Market? Lessons from Germany, Finland, the Czech Republic and the Netherlands. OECD Econ. Dep. Work. Pap. 2014, 1170. [CrossRef]

48. Młynarska, M. Kiedy Mieć Dziecko? Jakościowe Badanie Procesu Odraczania Decyzji o Rodzicielstwie. Psychol. Społeczna 2011, 6, 226-240.

49. GUS; CSO. Ludność. Stan i Struktura Oraz Ruch Naturalny w Przekroju Terytorialnym w 2016 r. Available online: https://stat.gov.pl/obszary-tematyczne/ludnosc/ludnosc/ludnosc-stan-i-struktura-orazruch-naturalny-w-przekroju-terytorialnym-stan-w-dniu-31-12-2016-r-,6,21.html (accessed on 30 May 2017).

50. Gyvbudas. Lietuva Pagal Gimdyvių Amžių Vejasi Vakarų Europą. Available online: https://www.lrytas.lt/ gyvenimo-budas/seima/2012/09/20/news/lietuva-pagal-gimdyviu-amziu-vejasi-vakaru-europa-5169000/ (accessed on 2 December 2019). 
51. Foryś, I. Społeczno-Gospodarcze Determinanty Rozwoju Rynku Mieszkaniowego w Polsce: Ujęcie Ilościowe. Rozpr. Stud. Szczec. 2011.

52. LS, S.L. Mums and dads in Lithuania. Available online: https://osp.stat.gov.lt (accessed on 15 November 2019).

53. Forlicz, S. Niedoskonała Wiedza Podmiotów Rynkowych; Wydawnictwo Naukowe PWN: Warsaw, Poland, 2001.

54. Charness, G.; Gneezy, U. Strong Evidence for Gender Differences in Risk Taking. J. Econ. Behav. Organ. 2012, 83, 50-58. [CrossRef]

55. Harris, C.R.; Jenkins, M. Gender Differences in Risk Assessment: Why Do Women Take Fewer Risks than Men? Judgement Decis. Mak. 2006, 1, 48-63.

56. Barber, B.M.; Odean, T. Boys Will Be Boys: Gender, Overconfidence, and Common Stock Investment. Q. J. Econ. 2001, 116, 261-292. [CrossRef]

57. Seagraves, P.; Gallimore, P. The Gender Gap in Real Estate Sales: Negotiation Skill or Agent Selection? Real Estate Econ. 2013, 41, 600-631. [CrossRef]

58. Drewicz-Tułodziecka, A. Nieruchomość Jako Przedmiot Obrotu i Zabezpieczenia w Polsce. Zesz. Hipoteczne 2008, 27, 2008.

59. Łaszek, J. Kryzysy w Sektorze Nieruchomości, w. Sobiecki R Pietrewicz JW Przedsiębiorstwo Glob. Kryzys SGH; 02-554; SGH Warszawa: Warszawa, Poland, 2010.

60. Statistics Lithuania. Statistical Yearbook of Lithuania 2017. Available online: https://osp.stat.gov.lt (accessed on 15 November 2019).

61. KNF. Wyniki Badania Portfela Kredytów Mieszkaniowych i Konsumpcyjnych Gospodarstw Domowych Według Stanu na Koniec 2018 r. Available online: https://www.knf.gov.pl (accessed on 15 May 2019).

62. Baranowska-Skimina, A. Polskie Kobiety a Rynek Nieruchomości. Available online: http://Www. Nieruchomosci.Egospodarka.Pl/82620,Polskie-Kobiety-a-Rynek-Nieruchomosci,2,79,1.Html (accessed on 5 December 2019).

63. Nieruchomości. Kobiety na Rynku Nieruchomości: Kupują i Zarządzaja. Available online: http://www.nieruchomosci. egospodarka.pl/155037,Kobiety-na-rynku-nieruchomoscikupuja-i-zarzadzaja,1,80,1.html (accessed on 5 August 2019).

64. SEB; BL. Annual Report 2017. Available online: https://sebgroup.com/investor-relations/reports-andpresentations/financial-reports/2017/annual-report-2017 (accessed on 12 November 2019).

65. Maśnica, A. Mieszkania Kupują Najczęściej Kobiety. Available online: https://krakow.wyborcza.pl/krakow/7, 44425,23726542,mieszkania-kupuja-najczesciej-kobiety.html?disableRedirects=true (accessed on 17 March 2019).

66. Dominium. Mieszkania-Niska Cena to za Mało! Available online: https://www.dominium.pl (accessed on 26 May 2019).

67. Walczak, A. Rynek mieszkań: Emeryci Sprzedaja, Trzydziestolatki Kupują. 2019. Available online: https://gratka.pl/blog/nieruchomosci/rynek-mieszkan-emeryci-sprzedaja-trzydziestolatki-kupuja/71761/ (accessed on 21 October 2019).

68. LB. Lietuvos Bankas-Statistics. Available online: https://www.lb.lt/en/lb-statistics (accessed on 15 November 2019).

69. Delfi.lt. Lietuviško Investavimo Ypatumai: Vyrams-Bitkoinai, Moterims—Butai Skaitykite Daugiau. Available online: https://www.delfi.lt/bustas/nt-rinka/lietuvisko-investavimo-ypatumai-vyrams-bitkoinaimoterims-butai.d?id=77527413 (accessed on 5 May 2019).

70. OECD. OECD Guidelines for Micro Statistics on Household Wealth. Available online: https: //www.oecd-ilibrary.org/docserver/9789264194878-18-en.pdf?expires=1585048675\&id=id\&accname= guest\&checksum=870C4FB3CD297928CE4F6A5EDC3D3136 (accessed on 8 May 2019).

71. Levy, D.S.; Lee, C.K.-C. The Influence of Family Members on Housing Purchase Decisions. J. Prop. Invest. Financ. 2004, 22, 320-338. [CrossRef]

72. Telyukova, I.; Nakajima, M. Home Equity Withdrawal in Retirement. In 2010 Meeting Papers; Society for Economic Dynamics: New York, NY, USA, 2010.

73. Cocco, J.F.; Gomes, F.J.; Maenhout, P.J. Consumption and Portfolio Choice over the Life Cycle. Rev. Financ. Stud. 2005, 18, 491-533. [CrossRef]

74. Yogo, M. Portfolio Choice in Retirement: Health Risk and the Demand for Annuities, Housing, and Risky Assets. J. Monet. Econ. 2016, 80, 17-34. [CrossRef]

75. Angelini, V.; Brugiavini, A.; Weber, G. The Dynamics of Homeownership among the 50+ in Europe. J. Popul. Econ. 2014, 27, 797-823. [CrossRef]

76. Chatfield, C.; Collins, A. Introduction to Multivariate Analysis; Routledge: New York, NY, USA, 2018; Volume 1, p. 248. 
77. Łapczyński, M. Analiza Porównawcza Tabel Kontyngencji i Metody CHAID. Zesz. Nauk. Ekon. W Krakowie 2005, 659, 149-163.

78. Sagan, A. Asymetryczne Metody Wielowymiarowe w Badaniach Marketingowych. Pr. Nauk. Uniw. Ekon. We Wroctawiu 2011, 236, 145-154.

79. Serlin, R.C.; Seaman, M.A. Log-Linear Analysis. In The Reviewer's Guide to Quantitative Methods in the Social Sciences; Routledge: New York, NY, USA, 2018; pp. 235-247.

80. Molenberghs, G. Multivariate Statistical Modelling Based on Generalized Linear Models. Biometrics 2001, 57, 1274.

81. Proto. The Increasing the Potential Client's Interest. Available online: https://www.proto.pl (accessed on 20 March 2020).

82. Kalinowska-Sołtys, A. Zrównoważony Czyli Jaki? Available online: https://builderpolska.pl/2020/03/04/ builder-marzec-2020/ (accessed on 4 March 2020).

83. Global Compact Network Poland, Zrównoważone Miasta. Poprawa Jakości Powietrza w Polsce 2018. Available online: https:/ungc.org.pl/wp-content/uploads/2018/12/Zrównoważone-Miasta.-Poprawa-jakościpowietrza-w-Polsce-2018.pdf (accessed on 20 March 2020).

84. Pałucha, K. Współpraca Przedsiębiorstw w Procesie Budowania Ich Potencjału Innowacyjnego. Zesz. Nauk. Organ. Zarządzanie Politech. Ślaska 2016, 93, 393-403.

(C) 2020 by the authors. Licensee MDPI, Basel, Switzerland. This article is an open access article distributed under the terms and conditions of the Creative Commons Attribution (CC BY) license (http://creativecommons.org/licenses/by/4.0/). 